\title{
Combination of Intensive Chemotherapy and Anticancer Vaccines in the Treatment of Human Malignancies: The Hematological Experience
}

\author{
Knut Liseth, ${ }^{1}$ Elisabeth Ersvær, ${ }^{2}$ Tor Hervig, ${ }^{1}$ and Øystein Bruserud ${ }^{2,3}$ \\ ${ }^{1}$ Department of Immunology and Transfusion Medicine, Haukeland University Hospital, 5021 Bergen, Norway \\ ${ }^{2}$ Department of Medicine, Section for Hematology, Haukeland University Hospital, 5021 Bergen, Norway \\ ${ }^{3}$ Institute of Internal Medicine, University of Bergen, Haukeland University Hospital, 5021 Bergen, Norway
}

Correspondence should be addressed to Øystein Bruserud, oystein.bruserud@haukeland.no

Received 30 November 2009; Accepted 20 March 2010

Academic Editor: Zhengguo Xiao

Copyright (C) 2010 Knut Liseth et al. This is an open access article distributed under the Creative Commons Attribution License, which permits unrestricted use, distribution, and reproduction in any medium, provided the original work is properly cited.

\begin{abstract}
In vitro studies have demonstrated that cancer-specific $\mathrm{T}$ cell cytotoxicity can be induced both ex vivo and in vivo, but this therapeutic strategy should probably be used as an integrated part of a cancer treatment regimen. Initial chemotherapy should be administered to reduce the cancer cell burden and disease-induced immune defects. This could be followed by autologous stem cell transplantation that is a safe procedure including both high-dose disease-directed chemotherapy and the possibility for ex vivo enrichment of the immunocompetent graft cells. The most intensive conventional chemotherapy and stem cell transplantation are used especially in the treatment of aggressive hematologic malignancies; both strategies induce T cell defects that may last for several months but cancer-specific $\mathrm{T}$ cell reactivity is maintained after both procedures. Enhancement of anticancer $\mathrm{T}$ cell cytotoxicity is possible but posttransplant vaccination therapy should probably be combined with optimalisation of immunoregulatory networks. Such combinatory regimens should be suitable for patients with aggressive hematological malignancies and probably also for other cancer patients.
\end{abstract}

\section{Introduction}

During the last two decades, effects of immunotherapy and autologous stem cell transplantation have been extensively studied in the treatment of human cancer. Immunotherapy often includes cancer vaccines, but vaccine-induced anticancer reactivity is often not associated with significant clinical responses [1-3]. Similarly, high-dose chemotherapy combined with autotransplantation has become a part of routine clinical practice only for a minority of cancer patients due to limited clinical benefits $[4,5]$.

Anticancer immune reactivity is probably important in autotransplantation, because early lymphoid reconstitution is associated with prolonged progression- or disease-free survival in many malignancies $[6,7]$. This has been described in patients with B-cell malignancies, acute myeloid leukemia (AML), and solid tumors, suggesting that early reconstitution represents a general anticancer effect [7-10]. Even though cancer patients often have both disease-associated and treatment-induced immune defects that may persist for several months [11], the combined use of autotransplantation and anticancer vaccines should be considered to try to increase anticancer effects.

In the present paper we review the experience with intensive chemotherapy and immunotherapy for patients receiving intensive chemotherapy for aggressive hematological malignancies. We focus on acute myeloid leukemia (AML), one of the most aggressive human malignancies that is usually treated with very intensive therapy eventually in combination with stem cell transplantation. The experience from these patients is that anticancer immune reactivity is maintained and can be induced after the intensive treatment. It seems likely that similar therapeutic strategies should be possible also in other patients receiving less intensive chemotherapy for less aggressive malignancies. 


\section{Effects of Conventional Intensive Chemotherapy on T Cells}

2.1. Early Effects of Chemotherapy on the T Cell System. Patients with acute myeloid leukemia receive intensive chemotherapy followed by a period of severe leukopenia, but even these patients have a functional T cell system, and rapid lymphoid reconstitution is associated with a decreased risk of AML relapse $[11,12]$. T cell functions during cytopenia are characterised by the following.

(i) Circulating $\mathrm{T}$ cells are mainly $\mathrm{T}$ cell receptor (TCR) $\alpha \beta^{+}$with only a minority of TCR $\gamma \delta^{+}$cells. The $\mathrm{CD} 4 / \mathrm{CD} 8$ ratio varies considerably between patients [13].

(ii) Chemotherapy-induced lymphopenia is not a random process and these patients have a decreased percentage of circulating clonogenic $\mathrm{T}$ cells. Their most important growth factors are IL-2 and IL-15, but several other cytokines can also cause detectable $\mathrm{T}$ cell proliferation [14]. $\mathrm{T}$ cell proliferation can be induced through the TCR-CD3 complex even in the presence of AML accessory cells [14], and responses are increased by CD28 mediated costimulation [15].

(iii) Activated $\mathrm{T}$ cells release several cytokines; high levels are detected for IFN $\gamma$, IL-6 and GM-CSF and detectable release of IL-2, IL-3, IL-4, IL-10, IL-13, and TNF $\alpha$ is often seen [16]. These responses can be enhanced by the protein kinase $\mathrm{C}$ agonist PEP005 [16].

(iv) Local $\mathrm{T}$ cell recruitment to the cancer cell compartment is essential for antileukemic $\mathrm{T}$ cell reactivity, and the chemotactic gradients are then determined by the systemic serum levels and the local levels in the cancer cell compartment. The systemic levels vary between patients and can be influenced by several factors, including the type of chemotherapy, patient age, and complicating febrile neutropenia [17]. Constitutive release of $\mathrm{T}$ cell chemotactic chemokines by the cancer cells may be an important determinant of the tissue chemokine levels [18].

Altogether, these observations clearly demonstrate that a functional $\mathrm{T}$ cell system remains during the severe posttreatment leukopenia even for patients receiving the most intensive conventional chemotherapy, and $\mathrm{T}$ cell targeting therapy may be possible even during this period.

2.2. Late Effects of Chemotherapy on Circulating T Cells. Studies of immunological reconstitution after conventional intensive chemotherapy has been carried out for patients with nonHodgkin's lymphoma, sarcomas and brain tumors, but these patients generally received less intensive chemotherapy than patients with AML [19-23]. These studies have described a decrease in circulating $\mathrm{CD}^{+}$cells that may last for several months, and there seems to be a predominance of memory-type (CD4 ${ }^{+} \mathrm{CD} 45 \mathrm{RO}^{+} \mathrm{CD}_{4} 5 \mathrm{RA}^{+/-}$) cells. This defect seems to be at least partly age-dependent and is less pronounced in children [23]. The number of $\mathrm{CD}^{-} \mathrm{CD}^{-} 6^{+} \mathrm{CD} 56^{+} \mathrm{NK}$ lymphocytes is usually normalised within 6 weeks [24]. It seems likely that similar defects are also seen after conventional chemotherapy for other malignancies, including the most intensive AML therapy. Certain drugs seem to cause more severe $\mathrm{CD} 4^{+} \mathrm{T}$ cell defects; this is especially true for fludarabine that can be used as a part of conventional chemotherapy and in the reduced intensity conditioning before allogeneic stem cell transplantation [25]. Finally, the effect of chemotherapy on Treg cells seem to differ between cytotoxic drugs as reviewed recently [26], myeloid suppressor cells can be transiently increased early after recovery from chemotherapy and the heterogeneity within the dendritic cell population varies during the recovery phase after chemotherapy [27]. The status of all these three cell types may influence the response to anticancer vaccines.

\section{Immunocompetent Cells in Autologous Stem Cell Grafts}

3.1. Sources of Hematopoietic Stem Cells: Bone Marrow versus Peripheral Blood Harvesting. Hematopoietic stem cells (HSC) are now preferably harvested from peripheral blood after growth factor mobilisation $[28,29]$, and this method is associated with earlier engraftment than HSC aspired from bone marrow [30]. Neutrophil engraftment with peripheral blood neutrophils $>0.1 \times 10^{9} / \mathrm{L}$ is usually seen within $10-$ 12 days and platelet engraftment with thrombocytes $>20$ $\times 10^{9} / \mathrm{L}$ within $12-14$ days $[30,31]$. The conclusion from the overall results is therefore very clear: (i) mobilisation of peripheral blood stem cells is safe and effective; and (ii) the short time until hematopoietic reconstitution when using mobilised cells has increased the safety of the procedure [32].

3.2. Preparation of Peripheral Blood Stem Cell Grafts. G-CSF is the most widely used drug for stem cell mobilisation [33] and is thought to stimulate immature stem cells to produce progenitors of all classes [34]. In addition G-CSF indirectly stimulates the production of progenitor cells by increasing the production of hematopoietic growth factors [35] and it promotes the release of progenitors into the general circulation [35]. When administered early after chemotherapy, G-CSF acts synergistically with the natural increase in HSC that is seen during the recovery phase [36]. The morbidity during and after G-CSF mobilisation is very low [37], and the most frequent side effects are bone pain, fever, and nausea. Successful mobilisation can also be achieved with longer-acting G-CSF (pegylated G-CSF) [38] its main advantage is less frequent administration [33].

Several strategies have been tried to increase the mobilisation of $\mathrm{CD} 4^{+}$cells. A combination of G-CSF plus stem cell factor (SCF) will often more than double the yield of CD $34^{+}$cells compared to G-CSF alone $[39,40]$. The CXCR4 antagonist AMD3100 can also be combined with G-CSF to improve HSC mobilisation [41-43]. Finally, even though mobilisation regimens that include chemotherapy have more side effects than G-CSF alone [37], the use of chemotherapy is appealing because insufficient mobilisation of $\mathrm{CD} 34^{+}$cells 
is more common in cancer patients with G-CSF alone [44], and the disease-specific chemotherapy in such regimens can have additional anticancer effects.

\subsection{Cryopreservation of Peripheral Blood Stem Cell Grafts:} Effects on Immunocompetent Cells. Autologous stem cell grafts are usually cryopreserved, and the protocols are generally based on the use of the cryoprotectant dimethyl sulphoxide (DMSO) in the freezing medium [45-47]. After harvesting, the final product is often diluted with autologous plasma if the nucleated cell concentration is higher than 200 $\times 10^{6}$ cells $/ \mathrm{mL}$ to improve cell viability [48]. Most centers will use a controlled programmed freezer and storage in nitrogen at $-160^{\circ} \mathrm{C}$.

The grafts are usually prepared by apheresis procedures alone without further enrichment of $\mathrm{CD}_{3} 4^{+}$stem cells, and large numbers of immunocompetent cells are therefore reinfused together with the stem cells. Early posttransplant lymphocyte reconstitution after both auto- and allotransplantation is associated with prolonged relapse-free survival in several malignancies [7-10]. For allotransplanted patients reconstitution of $\mathrm{CD} 4^{+} \mathrm{T}$ cells seems particularly important, and infusion of a high number of $\mathrm{CD} 4^{+} \mathrm{T}$ cells and NKT cells seems to be associated with a better prognosis [49]. This may also be true for autografted patients, and these observations suggest that immunological events early after reinfusion are important for the risk of later relapse/progression. The amount and quality of reinfused lymphocytes may therefore be essential.

We investigated the viability of total lymphocytes and the distribution of various $\mathrm{T}$ cell subsets in peripheral blood stem cell autografts after long-term storage with $2 \%, 4 \%, 5 \%$ and $10 \%$ DMSO [50]. The viability of the total lymphocyte population was significantly higher for cells preserved in $4 \%$ and $5 \%$ DMSO, but the DMSO effect differed between $\mathrm{T}$ cell subsets (Table 1). First, NKT cell viability was dependent on the DMSO concentration used. Second, naive and central memory $\mathrm{T}$ cells usually express CD62L, late effector $\mathrm{T}$ cells show intermediate/low expression, while effector memory $\mathrm{T}$ cells do not express CD62L [51]. The effect of DMSO differed between these CD62L-defined T cell subsets. Third, the CCR7 chemokine receptor is expressed by naive and central memory $\mathrm{T}$ cells and directs migration to lymph nodes; this homing process is important for initiation of immune responses [52]. Again the DMSO effect differed between CCR7defined subsets and also between CCR2/CCR4 defined subsets. Finally, Foxp3 positive $\mathrm{T}$ cells are referred to as thymus-derived natural $\mathrm{T}$ regulatory (Treg) cells [53]. The percentage of $\mathrm{CD}^{+} \mathrm{CD} 25^{+}$Foxp $3^{+}$cells among $\mathrm{CD} 4^{+} \mathrm{T}$ cells was significantly lower after cryopreservation with $10 \%$ DMSO.

Several NK cell subsets have now been characterised, including immunoregulatory $\left(\mathrm{CD} 3^{-} \mathrm{CD} 56^{\text {bright }} \mathrm{CD} 16^{\text {low/neg }}\right)$ and cytotoxic cells (CD3 $\left.{ }^{-} \mathrm{CD} 56^{\mathrm{dim}} \mathrm{CD} 16^{\text {bright }}\right)$ [54-56]. Cryopreservation with various DMSO concentrations did not alter the percentages among viable graft lymphocytes of total NK cells $\left(\mathrm{CD}^{-}{ }^{-} \mathrm{CD} 56^{+}\right)$or the various NK cell subsets [50].
Taken together these results suggest that the procedures used for cryopreservation affect lymphocyte viability; this is not a nonspecific effect but rather an effect that differs between various $\mathrm{T}$ cell subsets and it may thereby affect posttransplant $\mathrm{T}$ cell reconstitution and immunocompetence. The mobilisation and harvesting procedures would also be expected to influence the graft lymphocyte content but to the best of our knowledge this has not been investigated in clinical studies.

\subsection{Enhancement of Antileukemic Reactivity in Autologous} Stem Cell Grafts. The studies described above demonstrate that cytotoxic T cells are preserved and reinfused in autologous stem cell grafts. Furthermore, recent studies have demonstrated that $\mathrm{T}$ cells specific for leukemia-associated antigens remain in the circulation after intensive AML chemotherapy (see Section 5), and for this reason one would expect such cells also to be present in the autografts. At present it is not known whether reinfusion of such cells as a part of the transplantation procedure will have any clinical impact, or whether the immunocompetent cells in the graft will differ between various mobilisation procedures.

It is possible to separate graft cells into $\mathrm{CD} 34^{+}$and $\mathrm{CD}^{-} 4^{-}$cells before freezing [57], and the $\mathrm{CD} 34^{-}$subset could then be used for ex vivo enrichment of cancerreactive $\mathrm{T}$ cells before reinfusion together with the $\mathrm{CD} 34^{+}$ cells. Although techniques for enrichment of leukemiareactive $\mathrm{T}$ cells are available, they have not been used in a large-scale clinical setting in combination with stem cell transplantation.

3.5. The Possible Use of Ex Vivo Expanded Cancer-Reactive $T$ Cells. As stated above, in vitro expanded autologous $\mathrm{T}$ cells can be used in the treatment of cancer. This strategy has not been widely used in the aggressive hematological malignancies, but the experiences from solid tumors (e.g., malignant melanoma) suggest that such cells can induce clinically relevant antitumor activity $[27,58]$. In a recent study a comparable strategy was also used as a posttransplant treatment in allotransplanted patient; donor-derived leukemia-reactive $\mathrm{T}$ cells were then reinfused in patients with leukemia relapse after allotransplantation [59]. Taken together these studies suggest that infusion of ex vivo generated cancer-reactive $\mathrm{T}$ cells can be combined with high-dose chemotherapy and possible also with vaccination strategies.

\section{T Cell Reconstitution after Autotransplantation}

$\mathrm{T}$ cell functions during the early posttransplant period with severe treatment-induced leukopenia seem to be very similar to AML patients receiving intensive conventional chemotherapy, and the later reconstitution also shows many similarities [60] (Table 2). Time until complete immunological reconstitution in adults may take years [61-63]. However, after transplantation the absolute number of circulating $\mathrm{CD}^{+}$cells usually remains decreased for three to five months 
TABLE 1: Cryopreservation of autologous peripheral blood stem cell grafts in cancer patients; a summary of the effects on immunocompetent cells when grafts were prepared with $2 \%, 4 \%, 5 \%$, and $10 \%$ DMSO.

\begin{tabular}{lcc}
\hline T cell population & Functional characteristics & Effects of cryopreservation with DMSO at various concentrations \\
\hline $\begin{array}{l}\text { Major T cell subsets } \\
\mathrm{CD} 3^{+} \mathrm{CD} 4^{+}\end{array}$ & T helper & No effect of different DMSO levels \\
$\mathrm{CD}{ }^{+} \mathrm{CD} 8^{+}$ & Cytotoxic & No effect of different DMSO levels \\
$\mathrm{CD} 3^{+} \mathrm{CD} 56^{+} \mathrm{CD} 16^{+}$ & NK T cells & Highest viability with 2\% DMSO \\
$\mathrm{CD} 3^{+} \mathrm{CD} 56^{+} \mathrm{CD} 16^{-}$ & NK T cells & Highest viability with 2\% DMSO \\
\hline $\mathrm{CD} 62 \mathrm{~L}-$ defined subsets & & \\
$\mathrm{CD} 4^{+} \mathrm{CD} 62^{+}, \mathrm{CD} 8^{+} \mathrm{CD} 62^{+}$ & Naive and central memory & Highest viability when using DMSO 5\% \\
$\mathrm{CD} 4^{+} \mathrm{CD} 62^{\text {low }}, \mathrm{CD} 8^{+} \mathrm{CD} 62^{\text {low }}$ & Late effector T cells & $\mathrm{CD}^{+}$cells show highest viability with DMSO 2\% and 4\% \\
$\mathrm{CD} 4^{+} \mathrm{CD} 62^{-}, \mathrm{CD} 8^{+} \mathrm{CD} 62^{-}$ & Effector memory & No effect of different DMSO levels \\
\hline
\end{tabular}

Subsets defined by chemokine

receptor expression

\begin{tabular}{|c|c|c|}
\hline $\mathrm{CD}^{+}{ }^{+} \mathrm{CCR}^{+}, \mathrm{CD}^{+}{ }^{+} \mathrm{CCR}^{+}$ & Naive and central memory T cells & The $\mathrm{CD}^{+}$cells showed decreased viability when using $10 \%$ DMSO \\
\hline $\mathrm{CD}^{+}{ }^{+} \mathrm{CD} 45^{+} \mathrm{CCR}^{-} \mathrm{CCR}^{-}$ & & Decreased viability when using 2\% DMSO \\
\hline Other CCR2, CCR4, CCR7 & & No effect of different DMSO levels \\
\hline
\end{tabular}

$\mathrm{CD}^{+} \mathrm{CD} 25^{+} \mathrm{FoxP}^{+} \mathrm{T}$ cells $\quad$ Natural regulatory $\mathrm{T}$ cells $\quad$ Decreased viability when using $10 \%$ DMSO

Autografts were prepared for cancer patients after mobilisation with chemotherapy plus G-CSF. After the aphereses cell concentrations were adjusted and cells stored in nitrogen for 5-6 years as described in the text [50].

[64]. Low levels of circulating $\mathrm{CD}^{+}$cells have been reported for 12-18 months [65], whereas $\mathrm{CD}^{+} \mathrm{T}$ cells usually recover within 3-12 months [64]. Defective proliferation of both $\mathrm{CD}^{+}$and $\mathrm{CD}^{+} \mathrm{T}$ cells in response to antiCD3 and antiCD2 persists for at least for 2-4 months, and this seems to be caused by defective IL-2 responsiveness $[64,66]$. Furthermore, the specific cytotoxic $\mathrm{T}$ cell response against Epstein-Barr virus is significantly impaired for 2-5 months [67], whereas the frequency of circulating cytokine-secreting $\mathrm{T}$ helper cells and IL-2 responding T cells can be decreased for up to 5 years posttransplant [68].

Peripheral blood mobilized stem cells (PBMSC) are now used for most cancer patients treated with autologous stem cell transplantation. The immunological reconstitution differs between patients receiving peripheral blood and bone marrow autografts [64], and the following data on $\mathrm{T}$ cell subset reconstitution refers to patients transplanted with mobilized stem cells. PBMSC autografted patients show early recovery of $\mathrm{CD} 14^{+}$monocytes and $\mathrm{CD}^{+} 6^{+} \mathrm{NK}$ cells during the first month after autotransplantation $[64,69$, 70]. The homeostasis of total circulating dendritic cells is usually achieved relatively early after transplantation, although differences in dendritic cell subset composition may be detected for several months [70]. However, as pointed out by these authors the kinetics of dendritic cell reconstitution may differ between patients and also depend on the chemotherapy regimen [70]. In contrast, a longlasting $\mathrm{T}$ cell defect similar to chemotherapy-treated patients is also observed after autotransplantation [69, 70]. This defect is detected after 6 months for most patients, and for a minority the defect will last for more than a year [69].
TABLE 2: T cell reconstitution after autologous stem cell transplantation.

\begin{tabular}{lc}
\hline Immunocompetent cell & Time until reconstitution \\
\hline Number of circulating CD4 ${ }^{+}$T cells & $1-5$ years \\
Number of circulating CD ${ }^{+}$T cells & $3-12$ months \\
T cell proliferation & 3 months -5 years \\
T cell cytokine production & 6 months -5 years \\
T cell response to exogenous IL2 & 7 months -5 years \\
Cytotoxic T cells & 2 months -5 years \\
\hline
\end{tabular}

Adapted from article by Porrata et al. [60]. In general there is considerable variability in the data that have been found for $\mathrm{T}$ cell reconstitution, both in-between patients and studies. Thus, the timeframes indicate when the majority of patients can expect to reach normal values.

The total levels of $\mathrm{CD}^{+} \mathrm{T}$ cells seem to normalize within a few months, whereas total $\mathrm{CD}^{+} \mathrm{T}$ cell counts remain decreased for several months. The CD4 defect is mainly due to a reduction of naive $\mathrm{CD} 3^{+} \mathrm{CD} 4{ }^{+} \mathrm{CD} 45 \mathrm{RA}^{+} \mathrm{T}$ cells, and there seems to be a reduction even of $\mathrm{CD}^{+}$naive $\mathrm{T}$ cells $[69,70]$.

As discussed by Dreger age may influence the $\mathrm{T}$ cell reconstitution after autotransplantation [69]. Immunogenetic factors may also be important for posttransplant $\mathrm{T}$ cell functions; single nucleotide polimorphisms in immunoregulatory chemokine/cytokine genes seem to influence the risk of infections, graft versus host disease and leukemia relapse after allogeneic stem cell transplantation. (for a detailed discussion and additional references see 
Loeffler [71]). Such immunogenetic influences may also be important for the response to posttransplant vaccination therapy after conventional chemotherapy or stem cell transplantation.

The number of mature B cells is markedly decreased during the first 3 months posttransplant, but will thereafter gradually increase although complete normalisation may take up to 18 months [64]. Both $\mathrm{T}$ cell-dependent and independent $\mathrm{B}$ cell response are decreased for 12-18 months [72], and the IgM production will normalise earlier (often within 6 months) than the corresponding IgG response [72].

NK cells usually recover within 1 month after transplantation [73]. The NK cell number is often increased on day 15 posttransplant compared with normal individuals, but by day $75 \mathrm{NK}$ cell activity has usually returned to a normal level. NK cells are important for rejection of malignant cells [74], and pharmacological agents that increase cancer cell susceptibility to NK cell mediated lysis are now being developed [75].

As described in a recent review the immunological reconstitution after allogeneic stem cell transplantation differ between patients receiving myeloablative and reduced intensity conditioning therapy [25]. Briefly, allotransplantation is also associated with a similar quantitative defect in $\mathrm{CD} 4^{+} \mathrm{T}$ cells, this defect may last for several months but early normalization seems to be more common for patients receiving reduced intensity conditioning (for detailed discussion and additional references see [25].

\section{Induction of Anticancer Reactivity by Vaccination Is Possible in Heavily Pre-Treated Patients}

A major question is whether it is possible to induce anticancer $\mathrm{T}$ cell reactivity and especially cytotoxicity in patients who have recently received intensive chemotherapy. $T$ cells specific for cancer-associated antigens can be detected in healthy individuals and also in untreated cancer patients despite their disease-induced immunosuppression, and many of these cells seem to be $\mathrm{CD}^{+}$cytotoxic effector memory cells [76]. Many cancer patients develop additional therapy-induced immune defects. However, if it is possible to induce anticancer $\mathrm{T}$ cell reactivity by vaccination in AML patients who have a very aggressive disease and receive the most intensive chemotherapy, one would expect immunotherapy to be effective also in other cancer patients. Several strategies for immunotherapy in AML have been tried (Table 3). In this paper we will review the results from vaccination studies.

5.1. AML-Associated Peptide Antigens Used for Vaccination. AML patients are very heterogeneous with regard to genetic abnormalities encoding leukemia-specific antigens [77]. To find a common vaccination strategy the available studies have therefore focused on the use of either whole AML cells (cell lysates or modulated AML cells) or peptides derived from AML-associated proteins.
WT1 is a zinc finger transcription factor that is expressed in normal $\mathrm{CD}_{3} 4^{+}$hematopoietic cells, myoepithelal progenitors, renal podocytes, and some cells in testis and ovary [78]. This protein is overexpressed in several hematological malignancies and solid tumors [78]. Antibodies against this molecule have been detected in cancer patients and several immunogenic peptides have been identified [78]. Briefly, both CD4 and CD8 T cell epitopes have been identified, and HLA-A0201 and HLA-A24-restricted CD8 ${ }^{+}$ T cell cytotoxicity against WT1 expressing cancer cells have been detected. The CD4 peptides bind to different HLAclass II molecules and induce $\mathrm{CD} 4^{+} \mathrm{T}$ cell responses that enhance cytotoxic $\mathrm{T}$ cell reactivity either through induction of $\mathrm{CD}^{+}$cytotoxic $\mathrm{T}$ cells or through induction of $\mathrm{CD}^{+}$ Th1 helper cells. Some peptides include epitopes recognised both by $\mathrm{CD}^{+}$and $\mathrm{CD} 8^{+} \mathrm{T}$ cells. Finally, a recent study demonstrated that WT1-specific cytotoxic T cells remain even after remission-inducing intensive AML chemotherapy [79].

Proteinase 3 is a differentiation antigen that is also overexpressed in leukemic blasts [78]. A proteinase 3derived peptide named PR1 has been identified by screening for binding avidity to HLA-A0201 [78]. In vitro studies suggest that PR1-specific $\mathrm{T}$ cells can kill leukemic cells, including the more immature clonogenic subsets, but not normal hematopoietic stem cells $[78,80,81]$. However, it should be emphasized that these data are mainly based on studies of healthy individuals and cancer patients receiving low-toxicity chemotherapy. Untreated AML patients have also been investigated and circulating PR1 specific T cells could not be detected then [78]. This may be due to apoptosis of high-avidity $\mathrm{T}$ cells induced by exposure to high peptide concentrations or leukemic cells overexpressing the proteinase 3 [78]. However, PR1 specific T cells can be detected later after remission-inducing AML chemotherapy [79].

The receptor for hyaluronic-acid-mediated motility (RHAMM) is overexpressed in leukemic blasts from AML and CML patients but not in normal $\mathrm{CD} 34^{+}$hematopoietic cells [78]. Greiner et al. identified a RHAMM-derived peptide (referred to as the RHAMM-R3 peptide) that could be presented by HLA-A2 and recognised by $\mathrm{CD} 8^{+} \mathrm{T}$ cells $[78$, 83]. This peptide was a naturally processed $\mathrm{T}$ cell epitope, specific $\mathrm{T}$ cells were detected in AML patients even following intensive chemotherapy, and in vitro primed $\mathrm{T}$ cells could lyse human AML blasts.

Taken together these studies clearly demonstrate that cancer-specific, HLA-restricted T cell reactivity, including specific cytotoxicity, is maintained even after the most intensive chemotherapy.

5.2. Peptide Vaccination in AML. Oka et al. investigated the effect of WT1 peptide vaccination in 26 cancer patients, including 13 patients with de novo AML [84]. They used intradermal injection of a modified 9-mer WT1 peptide emulsified in Montanide ISA51 adjuvant; 18 of the 26 patients completed the vaccination protocol with 3 or more injections every second week and most patients were 
TABLE 3: Immunotherapy in AML; the advantages and disadvantages of the various approaches that have been investigated in clinical trials [82].

\begin{tabular}{|c|c|c|}
\hline Strategy & Advantage & Disadvantage \\
\hline Peptide vaccination & Easy to produce and administer & $\begin{array}{l}\text { Selection of patients with certain HLA } \\
\text { types and high antigen expression in the } \\
\text { malignant cells }\end{array}$ \\
\hline $\begin{array}{l}\text { Normal dendritic cells loaded } \\
\text { with AML-associated peptides }\end{array}$ & $\begin{array}{l}\text { Presentation of several leukemia-specific } \\
\text { and leukemia-associated antigens }\end{array}$ & $\begin{array}{l}\text { Work-consuming in vitro procedures for } \\
\text { preparation and antigenic loading } \\
\text { (lysates, mRNA). }\end{array}$ \\
\hline \multicolumn{3}{|l|}{$\begin{array}{l}\text { Whole tumor cell vaccines with } \\
\text { irradiated AML cells: }\end{array}$} \\
\hline $\begin{array}{l}\text { (i) Leukemic cells plus } \\
\text { systemic administration of } \\
\text { immunostimulatory } \\
\text { cytokines }\end{array}$ & $\begin{array}{l}\text { Relatively easy to prepare, several } \\
\text { antigens presented }\end{array}$ & Clinical side effects \\
\hline $\begin{array}{l}\text { (ii) Modified leukemic cells } \\
\text { expressing GM-CSF or } \\
\text { CD80+IL2 }\end{array}$ & Several antigens presented & $\begin{array}{l}\text { Complicated and work-consuming ex } \\
\text { vivo handling }\end{array}$ \\
\hline Leukemic dendritic cells & $\begin{array}{l}\text { Presentation of several leukemia-specific } \\
\text { and leukemia-associated antigens }\end{array}$ & $\begin{array}{l}\text { Heterogeneity between patients with } \\
\text { regard to efficiency; work-consuming in } \\
\text { vitro procedures for preparation and } \\
\text { antigenic loading (lysates, mRNA). }\end{array}$ \\
\hline IL-2 therapy & $\begin{array}{l}\text { Easy to administer, induces innate and } \\
\text { specific immunity }\end{array}$ & Serious side effects \\
\hline
\end{tabular}

vaccinated with a modified peptide that gave stronger cytotoxic $\mathrm{T}$ cell responses than the natural peptide. All patients were HLA-A2402 positive and their malignant cells showed high WT1 expression. Tetramer flow cytometry of circulating cells showed an increase in specific T cells during vaccination for 9 of the 13 AML patients. An increase in antigen-specific induction of IFN $\gamma$ expression was also observed for 6 of the patients. Only 10 of these patients could be evaluated with regard to clinical responses: (i) 2 patients showed decreased residual AML; (ii) stable disease was seen for 2 patients; (iii) bone marrow expression of WT1 was used as a surrogate marker of residual disease for those patients without detectable AML blasts, and for 5 of these patients decreased expression was detected following vaccination; (iv) 1 patient showed progressive disease. There was a statically significant correlation between clinical and immunological responsiveness. These observations suggest that WT1 vaccination can induce a specific T cell response; these $\mathrm{T}$ cells can locate to the bone marrow compartment and they mediate WT1-specific antileukemic effects.

Another study examined a regimen with GM-CSF therapy on days $1-4$ and vaccination with antigenic peptide + keyhole limpet hemocyanine on day 3 [1]. All patients were HLA-A2 positive and had high expression of WT1 in their leukemia cells, 17 out of the 19 included patients had received previous chemotherapy and all patients had detectable AML with increased bone marrow blasts. The vaccines induced immunological responses judged from tetramer analyses of peripheral blood, and a significant increase of these cells was also seen in the bone marrow. Importantly, responses were recorded especially in patients that had received previous chemotherapy and showed relatively low levels of bone marrow blasts $(<50 \%)$. Reduction of bone marrow WT1 levels was observed for a subset of patients following vaccination. Thus, previous intensive chemotherapy does not eradicate leukemia-reactive T cells; the chemotherapyinduced reduction of the AML cell burden rather seems to reduce disease-induced immune defects and thereby increase the efficiency of the vaccination.

PR1 responses have been investigated in a study that combined vaccination with WT1 and PR1 peptides [81]. This vaccine was also based on concomitant GM-CSF administration and subcutaneous administration of peptides in Montanide adjuvant. Five AML patients in complete remission after previous intensive chemotherapy were included. Responses were evaluated by tetramer staining, and immunological responses were detected for one or both peptides in most patients. Increased $\mathrm{T}$ cell responses were also detected by IFN $\gamma$ expression after specific stimulation. Bone marrow expression of WT1 was used as a surrogate marker for residual disease, and these levels decreased when immunological responses became detectable. Thus, even though in vitro exposure of PR1-specific T cells to AML cells with high antigen levels causes apoptosis of these cells (see Section 5.1), detectable PR1 T cell responses could be induced early after induction chemotherapy.

The RHAMM-R3 peptide identified in previous in vitro studies has been tried for vaccination in HLA-A2 ${ }^{+}$patients with hematological malignancies [85]. This study included only 10 patients with AML, MDS, or multiple myeloma; all 3 AML patients had received intensive chemotherapy before vaccination and the 4 myeloma patients had received autologous stem cell transplantation. The vaccine consisted of injection of $300 \mu \mathrm{g}$ peptide in incomplete Freund adjuvant 
subcutaneously on day 3, GM-CSF was administered on days 1 and 5, and this cycle was repeated 4 times with 2weeks intervals. Immunological responses were evaluated by tetramer flowcytometry and ELISpot analysis for IFN $\gamma$ and Granzyme B. An immunological response was detected by at least one of these methods for 9 patients, only 1 AML patient in relapse did not respond. Vaccinationinduced $\mathrm{T}$ cell cytotoxicity towards autologous AML cells or HLA-A2 ${ }^{+} \mathrm{RHAMM}^{+}$target cells could also be detected. A clinical response with further reduction of bone marrow blasts was observed for 1 AML and 2 MDS patients. This study illustrates that $\mathrm{T}$ cell reactivity against leukemiaassociated antigenic epitopes is maintained after intensive conventional chemotherapy as well as autologous stem cell transplantation, and this reactivity can be enhanced by peptide vaccination.

The clinical toxicity of vaccination was generally low, the most common side effect being grade 1-2 reactions with pain and erythema at the injection site. One study observed progressing leukopenia in two patients with MDS and MDSAML, respectively; this may be caused by immunological reactivity against normal stem cells in patients with diseaseinduced reduction of normal hematopoiesis [3]. Oka et al. also described a patient with a febrile reaction during the first injection [3].

5.3. Cell Vaccines. A recent article described two patients vaccinated with ex vivo generated monocytic dendritic cells that had been incubated with leukemic cell lysates and keyhole limpet hemocyanine [86]. Subcutaneous injection of the pulsed dendritic cells was well tolerated. Another study also investigated preparation of monocyte-derived dendritic cells in AML; these authors combined ex vivo generation of the cells followed by cryopreservation before transfection of WT1 mRNA by electroporation [87]. The procedure was successful for all patients and injections were well tolerated. It is difficult to see from these articles whether immunological responses were induced by the vaccination. An additional advantage with this approach could also be activation of NK cells and not only specific T cells and thereby induction of an additional anticancer effect [88].

Primary human AML cells can be induced to differentiate in the direction of a dendritic cell phenotype by exposure to various cytokines or cytokine combinations. These cells show dendritic morphology, increased expression of $\mathrm{T}$ cell costimulatory molecule, increased antigen-presenting capacity and a constitutive chemokine release profile consistent with a dendritic cell phenotype $[89,90]$. One study has reported the efficiency and toxicity when using a vaccine based on subcutaneous injection of dendritic AML cells [91]. Five patients treated in a palliative setting were included, and the authors observed increased immune responses towards a peptide derived from the leukemia-associated antigen PRAME. Thus, this methodological approach also seems to be effective and feasible. However, care should be taken when injecting ex vivo expanded cells, and possibly the cells should be irradiated before injection [89].
Even though the experience with dendritic cell vaccines in aggressive hematological malignancies is limited, the experience from other malignancies is promising [92]. The dendritic cells orchestrate a repertoire of immune responses, but various dendritic cell subsets differ in their immunoregulatory characteristics [93]. Dendritic cell vaccines can thereby be used for cross-presentation of cancer-associated antigens; a possible approach then being to load the cells with autologous cancer cell lysates [94]. This therapeutic strategy seems safe and effective. As an example, a recent study in patients with lung cell cancer showed no serious side effects and increased $\mathrm{T}$ cell responsiveness to cancer-associated antigens for more than half of the patients vaccinated with antigen-loaded autologous dendritic cells [94]. Another strategy is viral transfection of cancer-associated antigens alone or antigens together with various immunostimulatory molecules $[95,96]$. The experiences from other cancers suggest that such therapeutic strategies should be further investigated also in hematological malignancies, and combination of chemotherapy and dendritic cell vaccination should then be possible. However, the optimal procedures for antigenic loading and dendritic cell preparation remain to be established.

\section{Future Directions}

6.1. Design of the Chemotherapy in Combination Regimen. The general intensity of the chemotherapy has to be decided based on a clinical evaluation of the patients, and one has to take into consideration that there is evidence from clinical studies that a low cancer cell burden is associated with increased anticancer $\mathrm{T}$ cell reactivity $[1,97]$. Several additional points also have to be considered. Firstly, if possible one should use a regimen that induces immunogenic cancer cell apoptosis that will enhance anticancer immune reactivity; this has been described especially for the anthracyclines [98] (Figure 1). Second, if possible the chemotherapy should reduce the levels of regulatory T cells [99] (see Section 6.3). Finally, the vaccine studies described above started at least 4 weeks after chemotherapy, but even patients with severe chemotherapy-induced cytopenia have an operative $\mathrm{T}$ cell system and immunotherapy can probably start even earlier after chemotherapy [100].

6.2. The Advantage of Including Autologous Stem Cell Transplantation. There are several possible advantages if autotransplantation is combined with vaccination therapy. Firstly, additional disease-directed chemotherapy can be administered both for mobilisation and as high-dose intensive chemotherapy before transplantation; this is safe and may further reduce the cancer cell burden [101]. Secondly, graft preparation offers the possibility to manipulate the immunocompetent graft cells and thereby combine chemotherapy and immunotherapy. CD34 enrichment is now possible as a part of routine therapy before cryopreservation [102], and by using similar methodological approaches as previously used in experimental studies, one 


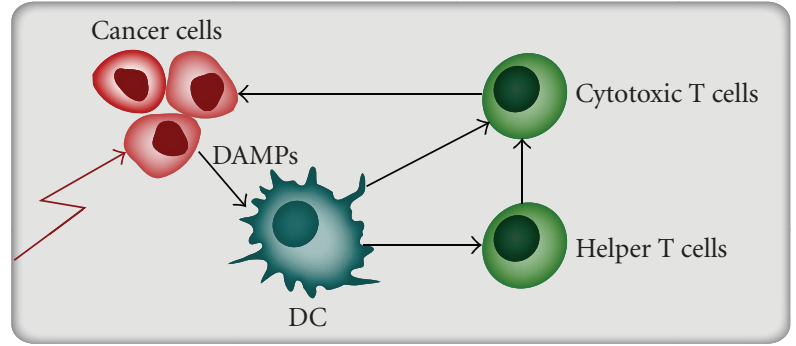

FIgURe 1: Induction of immunogenic apoptosis. Certain chemotherapeutics agents (e.g., the anthracyclines) will induce immunogenic apoptosis in cancer cell through induction of DangerAssociated Molecular Patterns (DAMPs). Examples of DAMPs are various Heat shock proteins and ecto-calreticulin exposure on the cancer cell surface. This pattern will induce dendritic cell (DC) maturation with development of specific $\mathrm{T}$ helper cell responses and enhancement of cancer-specific $\mathrm{T}$ cell cytotoxicity.

could enrich anticancer cytotoxic $\mathrm{T}$ cells and reinfuse them as a part of the transplantation procedure. Finally, even though both chemotherapy and autotransplantation seem to induce a general quantitative $\mathrm{CD} 4^{+} \mathrm{T}$ cell defect, intensive chemotherapy does not eradicate cancer-specific $\mathrm{T}$ cells and enhancement of this reactivity in graft immunocompetent cells or posttransplant cells should therefore be possible.

6.3. The Vaccination Procedure. The administration route of vaccines will probably be important. For example, animal experiments have shown that dendritic cells administered subcutaneously will localise to the draining lymph nodes, whereas intravenous administration will cause localisation to the spleen [103]. Several techniques are now available for preparation of the vaccines; these strategies have been reviewed recently and are exemplified by the results summarized in Figure 2 and Tables 3 and 4 [82, 104].

Manipulation of immunocompetent cells through stimulation of Toll-like receptors (TLR) seems to be of particular interest $[108,109]$. TLR9 is expressed by dendritic cells and B cells, and CpG oligonucleotides can be used as TLR9 agonists. These oligonucleotides will increase anticancer immune reactivity through several mechanisms, including increased presentation of cancer-associated antigens by dendritic cells [105-107, 110] (Figure 2). These agents have been used alone, but they can also be used as adjuvants in cancer vaccines and be combined with the Montanide adjuvant used in the peptide vaccines (see Section 5.2). However, the overall results from experimental and clinical studies with regard to effects of adjuvants on $\mathrm{T}$ regulator cells (Treg) are conflicting and require further studies.

Other adjuvants should also be tried in vaccination therapy, especially chemokines that are now considered as possible therapeutic targets in proinflammatory conditions [111]. These mediators can be released by malignant cells and have several biological effects including chemotactic, growth-stimulatory, immunomodulatory, and angioregulatory effects $[26,43,112]$. Other cytokines than GM-CSF are now investigated as vaccine adjuvants, including Fltsligand as well as the chemokine CCL5 and CXCL9 [113115]. These experiences from animal cancer models suggest that such approaches should be tried also in the treatment of human cancers, although the possible roles of chemokine decoy receptors have to be explored [116].

An alternative to in vivo expansion of antigen-specific $\mathrm{T}$ cells through vaccination would be ex vivo enrichment of specific cells followed by infusion of these cells. Based on experimental observations various strategies may be possible, including (i) stimulation and thereby in vitro prokiferation/expansion of antigen-specific $\mathrm{T}$ cells; or (ii) ex vivo generation of antigen-specific $\mathrm{T}$ cell reactivity through viral transduction of specific $\mathrm{T}$ cell receptor genes. First, antigen-loaded dendritic cells can be used to stimulate proliferation of cancer-specific cells, and this expansion can be increased by subsequent costimulation through CD28 $[117,118]$. Costimulation through the CD40/CD40-ligand system may also be possible [119]. Second, T cell receptor gene-modified lymphocytes can be generated, such cells persist in patients after infusion and reduction of tumor cell burden has been described $[120,121]$. Whether in vivo (vaccination) and ex vivo expansion (in vitro culture) of cancer-reactive $\mathrm{T}$ cells can be combined in cancer patients has not been clarified, and future studies also have to clarify whether these therapeutic strategies will be effective in hematologic malignancies.

6.4. Targeting of Immunoregulatory Cells Together with Leukemia-Specific Cytotoxicity: The Importance of Th17 Cells and Treg Cells. IL-17 is a family of T cell derived cytokines that triggers the production of proinflammatory cytokines and chemokines by a wide range of cells, including epithelial cells, endothelial cells and macrophages [122, 123]. In healthy individuals circulating Th17 cells constitute less than $1.0-1.5 \%$ of total circulating $\mathrm{T}$ cells [124], increased levels are observed in patients with advanced cancers, and tumor infiltrating Th17 cells have been detected in ovarian, pancreatic and renal cell cancer [125]. Several experimental observations suggest that Th17 cells can increase specific antitumor immune activity [126] as well as anticancer NK cell reactivity [127]. These animal studies suggest that the role of Th17 cells in human cancer should be further investigated, including the cryopreservation of Th17 cells in autologous stem cell grafts and the possibility to enhance anticancer reactivity through ex vivo enrichment of Th17 cells in the autografts before reinfusion.

Immunosuppressive Treg cells comprise $5-15 \%$ of peripheral $\mathrm{CD}^{+} \mathrm{T}$ cells $[128,129]$. In animal models these cells prevent autoimmune diseases, graft rejection and anticancer reactivity $[128,130]$. Several studies suggest that cytotoxic agents can alter the levels of Treg cells. Fludarabine therapy in patients with chronic lymphocytic leukemia often causes a decrease or abrogation of the activity of Treg cells [131]. Suppression of Treg cells by cyclophosphamide may allow immunotherapy of established tumors to be curative in animal models [132], but no effect is observed after a single cyclophosphamide infusion combined with nonspecific 


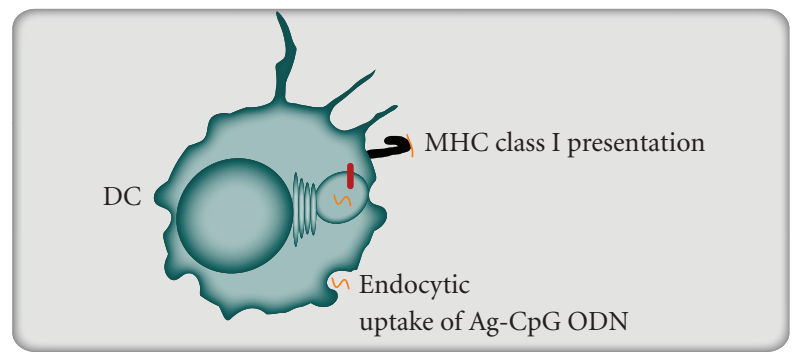

I TLR9

$\backsim$ Ag-CpG ODN

1 MHC class I

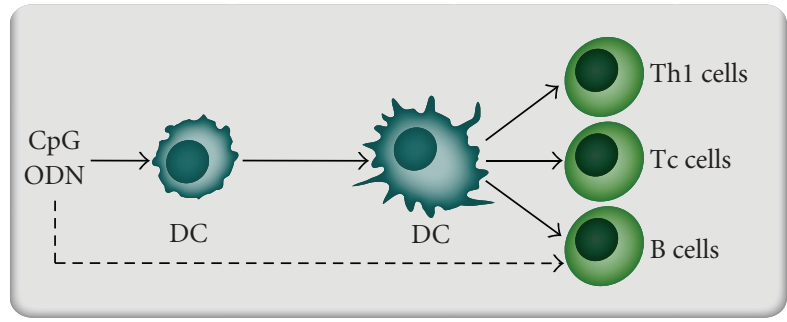

Recruitment of MyD88

个 IRAK

$\uparrow$ MAPK

$\uparrow$ IFN regulatory factors
个 NFkB transcription factors

$\uparrow$ Co-stimulatory molecules

$\uparrow$ Cytokine production (b)

(a)

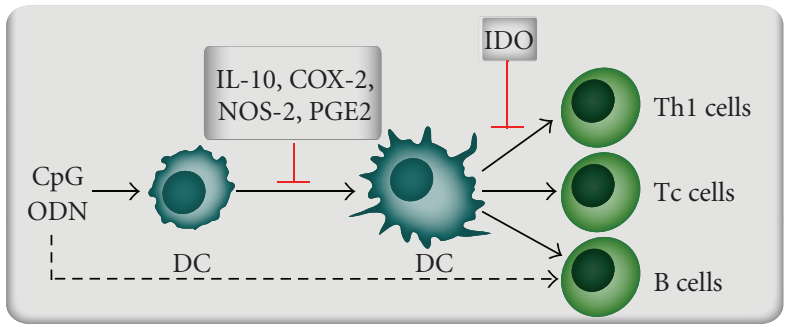

(c)

FIgURE 2: The immunostimulatory effect of TLR9 ligation by CpG oligonucleotides. (a) TLR9 is normally activated by nonmethylated CPG dinucleotides (DNA motifs). In vaccination therapy TLR9 can be activated by synthetic oligodeoxynucleotides (ODN) containing CpG motifs (CPG ODN), these molecules can be linked to antigenic peptides (Ag CpG ODN). This complex is endocytosed by dendritic cells (DC); the antigen is then presented and CpG ODN enhances the accessory cell function of the dendritic cells [105-107]. (b) Binding of CpG ODN by TLR9 ${ }^{+}$dendritic cells initiates signal transduction through members of the IL-1 receptor-associated kinase (IRAK) family, mitogen activated kinases (MAPK) or Interferon (IFN) regulatory factors. These events lead to activation of nuclear factor kappa $\mathrm{B}(\mathrm{NF} \kappa \mathrm{B})$ transcription factors with increased cytokine release and expression of costimulatory molecules [108]. (c) Inhibitory control mechanisms of CpG-mediated immune activation seem to include induction of IL-10, cyclooxygenase-2 (COX-2), NO synthase 2 (NOS-2) and prostaglandin E2 (PGE2). Intravenous administration of CpG ODN to mice induce splenic expression of the enzyme indoleamine 2,3dioxygenase (IDO) that is an enzyme associated generation of regulatory T cells (Treg) and thereby inhibition of Th1 cells, cytotoxic T cells (Tc cells) and B cells [108].

TABLe 4: Preparation of vaccines for lymphomas, an overview of possible methodological approaches [104].

Procedure Advantages

Improving antigen delivery

DNA vaccines

Liposomal vaccines

Increasing antigen presentation

Normal dendritic cell vaccines

CpG vaccines

Malignant dendritic cells
Skin or muscle injection of cDNA encoding the antigen. Protein is endogenously produced, and the epitopes can be combined with sequences from the carrier proteins or adjuvant proteins that increase immunogenicity

Antigens are supposed to be delivered both for endosomal $\left(\mathrm{CD} 4^{+}\right.$responses) and cytosolic processing $\left(\mathrm{CD}^{+}\right.$responses), combination with adjuvant is possible and custom-made vaccines can rapidly be produced.

Dendritic cells are regarded as the most powerful antigen-presenting cells; the cells can be pulsed by either cell lysates, heat shock proteins with bound client proteins or apoptotic cell organelles.

Dendritic cells are activated via toll-like receptors; these antigen-presenting cells will take up cancer-derived peptides and this approach thereby bypasses the step of custom-made vaccines. One approach is pre-vaccination local therapy that induces apoptosis, and local CpG-injection will then enhance the uptake and presentation of peptides derived from malignant cells

Can be prepared for various hematological malignancies; these cells will present several tumor-specific as well as tumor-associated antigens. 
immunotherapy in patients with metastatic carcinoma [133]. The mTOR antagonist rapamycin that is used in anticancer therapy, increases the number of Treg cells [134], whereas docetaxel does not seem to have any effect [135]. Thus, the effects of anticancer therapy on Treg levels seem to differ between therapeutic agents.

Previous studies in AML have demonstrated that increased Treg cells are detected in patients with newly diagnosed AML, and these high levels persist even after intensive chemotherapy and induction of disease control with hematological remission [136]. Thus, the overall intensity of the chemotherapy is not decisive for elimination of these cells; rather the design and use of specific drugs seem to be essential. Experimental studies have demonstrated that suppressive Treg cells can be stimulated to develop into proinflammatory Th17 cells [137]. The possibility to use this approach instead of chemotherapy for elimination of Treg cells and enhancement of immunoreactivity should be explored both with regard to ex vivo manipulation of stem cell grafts and in vivo immunomodulation.

6.5. The Roles of Immunogenetics. Many of the vaccination studies reviewed above included only patients with certain HLA-types known to bind and present the vaccine peptides. Future studies have to consider how vaccination strategies should be designed to include all patients and not only selected subsets. Other immunogenetic factors also need to be considered then, for example, genetic polymorphisms in the chemokine system [71] or in T cell regulatory molecules [110].

6.6. Final Comment. Available studies have demonstrated that cancer cell vaccines can induce anticancer immune reactivity. This is possible even for patients with the most aggressive hematological malignancies that are treated with very intensive chemotherapy, and it should therefore be possible also in other malignancies. The future challenge will now be to design optimal combinations of conventional disease-reducing therapy (chemotherapy, surgery, and irradiation), induction of antigen-specific immunity through vaccination and antigen-nonspecific immunomodulation (e.g., targeting of Treg and Th17 cells as well as NK cells) to enhance anticancer reactivity.

\section{References}

[1] U. Keilholz, A. Letsch, A. Busse, et al., "A clinical and immunologic phase 2 trial of Wilms tumor gene product 1 (WT1) peptide vaccination in patients with AML and MDS," Blood, vol. 113, no. 26, pp. 6541-6548, 2009.

[2] J. J. Molldrem, P. P. Lee, C. Wang, et al., "Evidence that specific T lymphocytes may participate in the elimination of chronic myelogenous leukemia," Nature Medicine, vol. 6, no. 9, pp. 1018-1023, 2000.

[3] Y. Oka, A. Tsuboi, T. Taguchi, et al., "Induction of WT1 (Wilms' tumor gene)-specific cytotoxic T lymphocytes by WT1 peptide vaccine and the resultant cancer regression," Proceedings of the National Academy of Sciences of the United States of America, vol. 101, no. 38, pp. 13885-13890, 2004.
[4] A. Smith, F. Wisloff, and D. Samson, "Guidelines on the diagnosis and management of multiple myeloma 2005," British Journal of Haematology, vol. 132, no. 4, pp. 410-451, 2006.

[5] K. Liseth, J. F. Abrahamsen, R. Ekanger, I. Nesthus, and M. S. Sjo, "Survival after high-dose therapy with autologous stem cell support," Tidsskrift for den Norske Laegeforening, vol. 124, no. 10, pp. 1374-1375, 2004.

[6] L. F. Porrata, M. R. Litzow, A. Tefferi, et al., "Early lymphocyte recovery is a predictive factor for prolonged survival after autologous hematopoietic stem cell transplantation for acute myelogenous leukemia," Leukemia, vol. 16, no. 7, pp. 13111318, 2002.

[7] L. F. Porrata and S. N. Markovic, "Timely reconstitution of immune competence affects clinical outcome following autologous stem cell transplantation," Clinical and Experimental Medicine, vol. 4, no. 2, pp. 78-85, 2004.

[8] L. F. Porrata, M. A. Gertz, D. J. Inwards, et al., "Early lymphocyte recovery predicts superior survival after autologous hematopoietic stem cell transplantation in multiple myeloma or non-Hodgkin lymphoma," Blood, vol. 98, no. 3, pp. 579585, 2001.

[9] R. Parkman, G. Cohen, S. L. Carter, et al., "Successful immune reconstitution decreases leukemic relapse and improves survival in recipients of unrelated cord blood transplantation," Biology of Blood and Marrow Transplantation, vol. 12, no. 9, pp. 919-927, 2006.

[10] D. H. Kim, S. K. Sohn, D. I. Won, N. Y. Lee, J. S. Suh, and K. B. Lee, "Rapid helper T-cell recovery above 200 $\times 106 / 1$ at 3 months correlates to successful transplant outcomes after allogeneic stem cell transplantation," Bone Marrow Transplantation, vol. 37, no. 12, pp. 1119-1128, 2006.

[11] E. Ersvær, J.-Y. Zhang, E. McCormack, et al., "Cyclin B1 is commonly expressed in the cytoplasm of primary human acute myelogenous leukemia cells and serves as a leukemiaassociated antigen associated with autoantibody response in a subset of patients," European Journal of Haematology, vol. 79, no. 3, pp. 210-225, 2007.

[12] D. Behl, L. F. Porrata, S. N. Markovic, et al., "Absolute lymphocyte count recovery after induction chemotherapy predicts superior survival in acute myelogenous leukemia," Leukemia, vol. 20, no. 1, pp. 29-34, 2006.

[13] O. Bruserud, E. Ulvestad, S. Berentsen, J. Bergheim, and I. Nesthus, "T-lymphocyte functions in acute leukaemia patients with severe chemotherapy-induced cytopenia: characterization of clonogenic T-cell proliferation," Scandinavian Journal of Immunology, vol. 47, no. 1, pp. 54-62, 1998.

[14] O. Bruserud, "Effects of imipenem and cilastatin on human T-lymphocytes derived from acute leukemia patients with chemotherapy-induced leucopenia: studies of T-lymphocyte responses in the presence of acute myelogenous leukemia (AML) blast accessory cells," International Journal of Immunopharmacology, vol. 22, no. 1, pp. 69-81, 2000.

[15] E. Ersvær, P. Hampson, O. Wendelbo, J. M. Lord, B. T. Gjertsen, and O. Bruserud, "Circulating T cells in patients with untreated acute myelogenous leukemia are heterogeneous and can be activated through the CD3/TCR complex," Hematology, vol. 12, no. 3, pp. 199-207, 2007.

[16] E. Ersvær, P. Hampson, K. Hatfield, et al., "T cells remaining after intensive chemotherapy for acute myelogenous leukemia show a broad cytokine release profile including high levels of interferon- $\gamma$ that can be further increased by a novel protein kinase C agonist PEP005," Cancer Immunology, Immunotherapy, vol. 56, no. 6, pp. 913-925, 2007. 
[17] A. M. Olsnes, A. Ryningen, E. Ersvær, and O. Bruserud, "In vitro induction of a dendritic cell phenotype in primary human acute myelogenous leukemia (AML) blasts alters the chemokine release profile and increases the levels of $\mathrm{T}$ cell chemotactic CCL17 and CCL22," Journal of Interferon and Cytokine Research, vol. 28, no. 5, pp. 297-310, 2008.

[18] A. M. Olsnes, E. Ersvær, A. Ryningen, and O. Bruserud, "Circulating $\mathrm{T}$ cells derived from acute leukemia patients with severe therapy-induced cytopenia express a wide range of chemokine receptors," Hematology, vol. 13, no. 6, pp. 329$332,2008$.

[19] C. L. Mackall, T. A. Fleisher, M. R. Brown, et al., "Distinctions between $\mathrm{CD}^{+}$and $\mathrm{CD}^{+}$T-cell regenerative pathways result in prolonged $\mathrm{T}$-cell subset imbalance after intensive chemotherapy," Blood, vol. 89, no. 10, pp. 3700-3707, 1997.

[20] G. M. Crooks, K. Weinberg, and C. Mackall, "Immune reconstitution: from stem cells to lymphocytes," Biology of Blood and Marrow Transplantation, vol. 12, supplement 1, pp. 42-46, 2006.

[21] J. C. Karl and C. L. Mackall, "Cancer therapy-induced immune modulation," Cancer Chemotherapy and Biological Response Modifiers, vol. 22, pp. 325-341, 2005.

[22] C. L. Mackall and L. J. Helman, "High-dose chemotherapy for rhabdomyosarcoma: where do we go from here," Journal of Pediatric Hematology and Oncology, vol. 23, no. 5, pp. 266267, 2001.

[23] C. L. Mackall, "T-cell immunodeficiency following cytotoxic antineoplastic therapy: a review," Stem Cells, vol. 18, no. 1, pp. 10-18, 2000.

[24] E. Ashihara, C. Shimazaki, N. Yamagata, et al., "Reconstitution of lymphocyte subsets after peripheral blood stem cell transplantation: two-color flow cytometric analysis," Bone Marrow Transplantation, vol. 13, no. 4, pp. 377-381, 1994.

[25] M. Jimenez, G. Ercilla, and C. Martinez, "Immune reconstitution after allogeneic stem cell transplantation with reduced-intensity conditioning regimens," Leukemia, vol. 21, no. 8 , pp. 1628-1637, 2007.

[26] O. Bruserud and A. O. Kittang, "The chemokine system in experimental and clinical hematology," Current Topics in Microbiology and Immunology. In press.

[27] M. L. Salem and D. J. Cole, "Dendritic cell recovery postlymphodepletion: a potential mechanism for anti-cancer adoptive T cell therapy and vaccination," Cancer Immunology, Immunotherapy, vol. 59, no. 3, pp. 341-353, 2010.

[28] M. A. Socinski, S. A. Cannistra, A. Elias, K. H. Antman, L. Schnipper, and J. D. Griffin, "Granulocyte-macrophage colony stimulating factor expands the circulating haemopoietic progenitor cell compartment in man," The Lancet, vol. 1, no. 8596, pp. 1194-1198, 1988.

[29] M. A. Socinski, S. A. Cannistra, R. Sullivan, et al., "Granulocyte-macrophage colony-stimulating factor induces the expression of the CD11b surface adhesion molecule on human granulocytes in vivo," Blood, vol. 72, no. 2, pp. 691$697,1988$.

[30] E. Vellenga, M. van Agthoven, A. J. Croockewit, et al., "Autologous peripheral blood stem cell transplantation in patients with relapsed lymphoma results in accelerated haematopoietic reconstitution, improved quality of life and cost reduction compared with bone marrow transplantation: the Hovon 22 study," British Journal of Haematology, vol. 114, no. 2, pp. 319-326, 2001.

[31] J. M. Vose, G. Sharp, W. C. Chan, et al., "Autologous transplantation for aggressive non-Hodgkin's lymphoma: results of a randomized trial evaluating graft source and minimal residual disease," Journal of Clinical Oncology, vol. 20, no. 9, pp. 2344-2352, 2002.

[32] M. Körbling and P. Anderlini, "Peripheral blood stem cell versus bone marrow allotransplantation: does the source of hematopoietic stem cells matter?" Blood, vol. 98, no. 10, pp. 2900-2908, 2001.

[33] T. J. Smith, J. Khatcheressian, G. H. Lyman, et al., “2006 Update of recommendations for the use of white blood cell growth factors: an evidence-based clinical practice guideline," Journal of Clinical Oncology, vol. 24, no. 19, pp. 31873205, 2006.

[34] J.-P. Levesque, Y. Takamatsu, S. K. Nilsson, D. N. Haylock, and P. J. Simmons, "Vascular cell adhesion molecule-1 (CD106) is cleaved by neutrophil proteases in the bone marrow following hematopoietic progenitor cell mobilization by granulocyte colony-stimulating factor," Blood, vol. 98, no. 5, pp. 1289-1297, 2001.

[35] M. Korbling, Y. O. Huh, A. Durett, et al., "Allogeneic blood stem cell transplantation: peripheralization and yield of donor-derived primitive hematopoietic progenitor cells $\left(\mathrm{CD} 34^{+}\right.$Thy-1(dim)) and lymphoid subsets, and possible predictors of engraftment and graft-versus-host disease," Blood, vol. 86, no. 7, pp. 2842-2848, 1995.

[36] E. A. Copelan, S. K. Ceselski, S. A. Ezzone, et al., "Mobilization of peripheral-blood progenitor cells with highdose etoposide and granulocyte colony-stimulating factor in patients with breast cancer, non-Hodgkin's lymphoma, and Hodgkin's disease," Journal of Clinical Oncology, vol. 15, no. 2, pp. 759-765, 1997.

[37] O. N. Koc, S. L. Gerson, B. W. Cooper, et al., "Randomized cross-over trial of progenitor-cell mobilization: highdose cyclophosphamide plus granulocyte colony-stimulating factor (G-CSF) versus granulocyte-macrophage colonystimulating factor plus G-CSF," Journal of Clinical Oncology, vol. 18, no. 9, pp. 1824-1830, 2000.

[38] A. Isidori, M. Tani, F. Bonifazi, et al., "Phase II study of a single pegfilgrastim injection as an adjunct to chemotherapy to mobilize stem cells into the peripheral blood of pretreated lymphoma patients," Haematologica, vol. 90, no. 2, pp. 225231, 2005.

[39] J. A. Glaspy, E. J. Shpall, C. F. LeMaistre, et al., "Peripheral blood progenitor cell mobilization using stem cell factor in combination with filgrastim in breast cancer patients," Blood, vol. 90, no. 8, pp. 2939-2951, 1997.

[40] E. J. Shpall, "The utilization of cytokines in stem cell mobilization strategies," Bone Marrow Transplantation, vol. 23, supplement 2, pp. S13-S19, 1999.

[41] G. Calandra, J. McCarty, J. McGuirk, et al., "AMD3100 plus G-CSF can successfully mobilize CD $34^{+}$cells from non-Hodgkin's lymphoma, Hodgkin's disease and multiple myeloma patients previously failing mobilization with chemotherapy and/or cytokine treatment: compassionate use data," Bone Marrow Transplantation, vol. 41, no. 4, pp. 331338, 2008.

[42] N. Flomenberg, S. M. Devine, J. F. DiPersio, et al., "The use of AMD3100 plus G-CSF for autologous hematopoietic progenitor cell mobilization is superior to G-CSF alone," Blood, vol. 106, no. 5, pp. 1867-1874, 2005.

[43] G. Calandra, G. Bridger, and S. Fricker, "CXCR4 in clinical hematology," Current Topics in Microbiology and Immunology. In press.

[44] W. Bensinger, F. Appelbaum, S. Rowley, et al., "Factors that influence collection and engraftment of autologous 
peripheral-blood stem cells," Journal of Clinical Oncology, vol. 13, no. 10, pp. 2547-2555, 1995.

[45] J. M. Goldman, K. H. Th'ng, and D. S. Park, "Collection, cryopreservation and subsequent viability of haemopoietic stem cells intended for treatment of chronic granulocytic leukaemia in blast-cell transformation," British Journal of Haematology, vol. 40, no. 2, pp. 185-195, 1978.

[46] D. English, "Freezing hematopoietic stem cells," Journal of Hematotherapy and Stem Cell Research, vol. 9, no. 2, pp. 123$125,2000$.

[47] C. Scheinkonig, S. Kappicht, H.-J. Kolb, and M. Schleuning, "Adoption of long-term cultures to evaluate the cryoprotective potential of trehalose for freezing hematopoietic stem cells," Bone Marrow Transplantation, vol. 34, no. 6, pp. 531536, 2004.

[48] K. Liseth, J. F. Abrahamsen, S. Bjorsvik, K. Grottebo, and O. Bruserud, "The viability of cryopreserved PBPC depends on the DMSO concentration and the concentration of nucleated cells in the graft," Cytotherapy, vol. 7, no. 4, pp. 328-333, 2005.

[49] J. Vela-Ojeda, M. A. Garcia-Ruiz Esparza, E. ReyesMaldonado, et al., "Clinical relevance of NK, NKT, and dendritic cell dose in patients receiving G-CSF-mobilized peripheral blood allogeneic stem cell transplantation," Annals of Hematology, vol. 85, no. 2, pp. 113-120, 2006.

[50] K. Liseth, E. Ersvær, J. F. Abrahamsen, I. Nesthus, A. Ryningen, and O. Bruserud, "Long-term cryopreservation of autologous stem cell grafts: a clinical and experimental study of hematopoietic and immunocompetent cells," Transfusion, vol. 49, no. 8, pp. 1709-1719, 2009.

[51] H. Unsoeld and H. Pircher, "Complex memory T-cell phenotypes revealed by coexpression of CD62L and CCR7," Journal of Virology, vol. 79, no. 7, pp. 4510-4513, 2005.

[52] F. Sallusto, D. Lenig, R. Forster, M. Lipp, and A. Lanzavecchia, "Two subsets of memory $\mathrm{T}$ lymphocytes with distinct homing potentials and effector functions," Nature, vol. 401, no. 6754, pp. 708-712, 1999.

[53] M. A. Curotto de Lafaille and J. J. Lafaille, "Natural and adaptive foxp3+ regulatory $\mathrm{T}$ cells: more of the same or a division of labor?” Immunity, vol. 30, no. 5, pp. 626-635, 2009.

[54] J. Yu, H. C. Mao, M. Wei, et al., "CD94 surface density identifies a functional intermediary between the CD56bright and CD56dim human NK-cell subsets," Blood, vol. 115, no. 2, pp. 274-281, 2010.

[55] J. Rolin, K. L. Sand, E. Knudsen, and A. A. Maghazachi, "FTY720 and SEW2871 reverse the inhibitory effect of S1P on natural killer cell mediated lysis of K562 tumor cells and dendritic cells but not on cytokine release," Cancer Immunology, Immunotherapy, vol. 59, no. 4, pp. 575-586, 2010.

[56] A. A. Maghazachi, "Role of chemokines in the biology of natural killer cells," Current Topics in Microbiology and Immunology. In press.

[57] S. Miltenyi, "CD34 selection: the basic component for graft engineering," Oncologist, vol. 2, no. 6, pp. 410-413, 1997.

[58] K. L. Knutson and M. L. Disis, "Tumor antigen-specific $\mathrm{T}$ helper cells in cancer immunity and immunotherapy," Cancer Immunology, Immunotherapy, vol. 54, no. 8, pp. 721$728,2005$.

[59] E. H. Warren, N. Fujii, Y. Akatsuka, et al., "Therapy of relapsed leukemia after allogeneic hematopoietic cell transplantation with $\mathrm{T}$ cells specific for minor histocompatibility antigens," Blood, vol. 115, no. 19, pp. 3869-3878, 2010.
[60] L. F. Porrata, M. R. Litzow, and S. N. Markovic, "Immune reconstitution after autologous hematopoietic stem cell transplantation," Mayo Clinic Proceedings, vol. 76, no. 4, pp. 407-412, 2001.

[61] T. Guillaume, D. B. Rubinstein, and M. Symann, "Immune reconstitution and immunotherapy after autologous hematopoietic stem cell transplantation," Blood, vol. 92, no. 5, pp. 1471-1490, 1998.

[62] I. Yakoub-Agha, P. Saule, L. Magro, et al., "Immune reconstitution following myeloablative allogeneic hematopoietic stem cell transplantation: the impact of expanding CD28negative CD8 ${ }^{+}$T cells on relapse," Biology of Blood and Marrow Transplantation, vol. 15, no. 4, pp. 496-504, 2009.

[63] M. Cavazzana-Calvo, I. Andre-Schmutz, L. Dal Cortivo, B. Neven, S. Hacein-Bey-Abina, and A. Fischer, "Immune reconstitution after haematopoietic stem cell transplantation: obstacles and anticipated progress," Current Opinion in Immunology, vol. 21, no. 5, pp. 544-548, 2009.

[64] J. E. Talmadge, E. Reed, K. Ino, et al., "Rapid immunologic reconstitution following transplantation with mobilized peripheral blood stem cells as compared to bone marrow," Bone Marrow Transplantation, vol. 19, no. 2, pp. 161-172, 1997.

[65] C. L. Mackall, D. Stein, T. A. Fleisher, et al., "Prolonged CD4 depletion after sequential autologous peripheral blood progenitor cell infusions in children and young adults," Blood, vol. 96, no. 2, pp. 754-762, 2000.

[66] S. Cayeux, S. Meuer, A. Pezzutto, et al., "T-cell ontogeny after autologous bone marrow transplantation: failure to synthesize interleukin-2 (IL-2) and lack of CD2- and CD3mediated proliferation by both $\mathrm{CD}^{-}$and $\mathrm{CD} 8^{+}$cells even in the presence of exogeneous IL-2," Blood, vol. 74, no. 6, pp. 2270-2277, 1989.

[67] A. Nolte, R. Buhmann, C. Straka, B. Emmerich, and M. Hallek, "Assessment and characterization of the cytolytic T lymphocyte response against Epstein-Barr virus in patients with non-Hodgkin's lymphoma after autologous peripheral blood stem cell transplantation," Bone Marrow Transplantation, vol. 21, no. 9, pp. 909-916, 1998.

[68] R. A. Miller, J. Daley, R. Ghalie, and H. Kaizer, "Clonal analysis of T-cell deficiencies in autotransplant recipients," Blood, vol. 77, no. 8, pp. 1845-1850, 1991.

[69] P. Dreger, K. Viehmann, N. von Neuhoff, et al., "Autografting of highly purified peripheral blood progenitor cells following myeloablative therapy in patients with lymphoma: a prospective study of the long-term effects on tumor eradication, reconstitution of hematopoiesis and immune recovery," Bone Marrow Transplantation, vol. 24, no. 2, pp. 153-161, 1999.

[70] A. Galy, S. Rudraraju, R. Baynes, and J. Klein, "Recovery of lymphocyte and dendritic cell subsets after autologous CD34 ${ }^{+}$cell transplantation," Bone Marrow Transplantation, vol. 25, no. 12, pp. 1249-1255, 2000.

[71] J. Loeffler, M. Ok, O. C. Morton, M. Mezger, and H. Einsele, "Genetic polymorphisms in the cytokine and chemokine system: Their possible importance in allogeneic stem cell transplantation," Current Topics in Microbiology and Immunology. In press.

[72] J. Storek, S. Ferrara, N. Ku, J. V. Giorgi, R. E. Champlin, and A. Saxon, "B cell reconstitution after human bone marrow transplantation: recapitulation of ontogeny?" Bone Marrow Transplantation, vol. 12, no. 4, pp. 387-398, 1993.

[73] G. H. Marin, M. C. Mendez, M. E. Menna, et al., "Immune recovery after bone marrow and peripheral blood stem cells 
transplantation," Transplantation Proceedings, vol. 31, no. 6, pp. 2582-2584, 1999.

[74] J. Tanaka, M. Asaka, and M. Imamura, "Potential role of natural killer cell receptor-expressing cells in immunotherapy for leukemia," International Journal of Hematology, vol. 81, no. 1, pp. 6-12, 2005.

[75] J. Rolin, K. L. Sand, E. Knudsen, and A. A. Maghazachi, "FTY720 and SEW2871 reverse the inhibitory effect of S1P on natural killer cell mediated lysis of K562 tumor cells and dendritic cells but not on cytokine release," Cancer Immunology, Immunotherapy, vol. 59, no. 4, pp. 575-586, 2010.

[76] G. Weber, J. Karbach, S. Kuci, et al., "WT1 peptide-specific $\mathrm{T}$ cells generated from peripheral blood of healthy donors: possible implications for adoptive immunotherapy after allogeneic stem cell transplantation," Leukemia, vol. 23, no. 9, pp. 1634-1642, 2009.

[77] F. O. Smith, W. H. Raskind, P. J. Fialkow, and I. D. Bernstein, "Cellular biology of acute myelogenous leukemia," Journal of Pediatric Hematology and Oncology, vol. 17, no. 2, pp. 113122, 1995.

[78] T. Dao and D. A. Scheinberg, "Peptide vaccines for myeloid leukaemias," Best Practice and Research: Clinical Haematology, vol. 21, no. 3, pp. 391-404, 2008.

[79] C. Scheibenbogen, A. Letsch, E. Thiel, et al., "CD8 T-cell responses to Wilms tumor gene product WT1 and proteinase 3 in patients with acute myeloid leukemia," Blood, vol. 100, no. 6, pp. 2132-2137, 2002.

[80] K. Rezvani, "PR1 vaccination in myeloid malignancies," Expert Review of Vaccines, vol. 7, no. 7, pp. 867-875, 2008.

[81] K. Rezvani, A. S. M. Yong, S. Mielke, et al., "Leukemiaassociated antigen-specific T-cell responses following combined PR1 and WT1 peptide vaccination in patients with myeloid malignancies," Blood, vol. 111, no. 1, pp. 236-242, 2008.

[82] E. L. J. M. Smits, Z. N. Berneman, and V. F. I. Van Tendeloo, "Immunotherapy of acute myeloid leukemia: current approaches," Oncologist, vol. 14, no. 3, pp. 240-252, 2009.

[83] J. Greiner, M. Schmitt, L. Li, et al., "Expression of tumorassociated antigens in acute myeloid leukemia: implications for specific immunotherapeutic approaches," Blood, vol. 108, no. 13, pp. 4109-4117, 2006.

[84] Y. Oka, A. Tsuboi, T. Taguchi, et al., "Induction of WT1 (Wilms' tumor gene)-specific cytotoxic $\mathrm{T}$ lymphocytes by WT1 peptide vaccine and the resultant cancer regression," Proceedings of the National Academy of Sciences of the United States of America, vol. 101, no. 38, pp. 13885-13890, 2004.

[85] M. Schmitt, A. Schmitt, M. T. Rojewski, et al., "RHAMM-R3 peptide vaccination in patients with acute myeloid leukemia, myelodysplastic syndrome, and multiple myeloma elicits immunologic and clinical responses," Blood, vol. 111, no. 3, pp. 1357-1365, 2008.

[86] L. Li, K. Giannopoulos, P. Reinhardt, et al., "Immunotherapy for patients with acute myeloid leukemia using autologous dendritic cells generated from leukemic blasts," International Journal of Oncology, vol. 28, no. 4, pp. 855-861, 2006.

[87] J.-J. Lee, H. Kook, M.-S. Park, et al., "Immunotherapy using autologous monocyte-derived dendritic cells pulsed with leukemic cell lysates for acute myeloid leukemia relapse after autologous peripheral blood stem cell transplantation," Journal of Clinical Apheresis, vol. 19, no. 2, pp. 66-70, 2004.
[88] T. Osada, T. Clay, A. Hobeika, H. K. Lyerly, and M. A. Morse, "NK cell activation by dendritic cell vaccine: a mechanism of action for clinical activity," Cancer Immunology, Immunotherapy, vol. 55, no. 9, pp. 1122-1131, 2006.

[89] O. Bruserud, B. T. Gjertsen, B. Foss, and T.-S. Huang, "New strategies in the treatment of acute myelogenous leukemia (AML): in vitro culture of AML cells-The present use in experimental studies and the possible importance for future therapeutic approaches," Stem Cells, vol. 19, no. 1, pp. 1-11, 2001.

[90] A. M. Olsnes, A. Ryningen, E. Ersvær, and O. Bruserud, "In vitro induction of a dendritic cell phenotype in primary human acute myelogenous leukemia (AML) blasts alters the chemokine release profile and increases the levels of $\mathrm{T}$ cell chemotactic CCL17 and CCL22," Journal of Interferon and Cytokine Research, vol. 28, no. 5, pp. 297-310, 2008.

[91] K. Giannopoulos, L. Li, A. Bojarska-Junak, et al., "Expression of RHAMM/CD168 and other tumor-associated antigens in patients with B-cell chronic lymphocytic leukemia," International Journal of Oncology, vol. 29, no. 1, pp. 95-103, 2006.

[92] C. J. M. Melief, "Cancer immunotherapy by dendritic cells," Immunity, vol. 29, no. 3, pp. 372-383, 2008.

[93] J. Banchereau, E. Klechevsky, N. Schmitt, R. Morita, K. Palucka, and H. Ueno, "Harnessing human dendritic cell subsets to design novel vaccines," Annals of the New York Academy of Sciences, vol. 1174, pp. 24-32, 2009.

[94] S. J. Um, Y. J. Choi, H. J. Shin, et al., "Phase I study of autologous dendritic cell tumor vaccine in patients with nonsmall cell lung cancer," Lung Cancer. In press.

[95] L. J. Chang, "Lentiviral vector transduction of dendritic cells for novel vaccine strategies," Methods in Molecular Biology, vol. 614, pp. 161-171, 2010.

[96] H. S. Kim, C. H. Kim, M. Y. Park, et al., "Efficient cotransduction of adenoviral vectors encoding carcinoembryonic antigen and surviving into dendritic cells by the CARTAT adaptor molecule enhance anti-tumor immunity in a murine colorectal cancer model," Immunology Letters. In press.

[97] U. Winters, S. Daayana, J. T. Lear, et al., "Clinical and immunologic results of a phase II trial of sequential imiquimod and photodynamic therapy for vulval intraepithelial neoplasia," Clinical Cancer Research, vol. 14, no. 16, pp. 5292-5299, 2008.

[98] G. Gausdal, B. T. Gjertsen, E. McCormack, et al., "Abolition of stress-induced protein synthesis sensitizes leukemia cells to anthracycline-induced death," Blood, vol. 111, no. 5, pp. 2866-2877, 2008.

[99] R. Houot, M. J. Goldstein, H. E. Kohrt, et al., "Therapeutic effect of CD137 immunomodulation in lymphoma and its enhancement by Treg depletion," Blood, vol. 114, no. 16, pp. 3431-3438, 2009.

[100] O. Bruserud, E. Ersvær, A. Olsnes, and B. T. Gjertsen, "Anticancer immunotherapy in combination with proapoptotic therapy," Current Cancer Drug Targets, vol. 8, no. 8, pp. 666675, 2008.

[101] A. M. Carella, N. Pollicardo, E. Pungolino, et al., "Mobilization of cytogenetically 'Normal' blood progenitors cells by intensive conventional chemotherapy for chronic myeloid and acute lymphoblastic leukemia," Leukemia and Lymphoma, vol. 9, no. 6, pp. 477-483, 1993.

[102] J. C. Wojciechowski, S. D. Narasipura, N. Charles, et al., "Capture and enrichment of CD34-positive haematopoietic stem and progenitor cells from blood circulation using 
P-selectin in an implantable device," British Journal of Haematology, vol. 140, no. 6, pp. 673-681, 2008.

[103] S. P. Huck, S.-C. Tang, K. A. Andrew, J. Yang, J. L. Harper, and F. Ronchese, "Activation and route of administration both determine the ability of bone marrow-derived dendritic cells to accumulate in secondary lymphoid organs and prime $\mathrm{CD}^{+} \mathrm{T}$ cells against tumors," Cancer Immunology, Immunotherapy, vol. 57, no. 1, pp. 63-71, 2008.

[104] R. Houot and R. Levy, "Vaccines for lymphomas: idiotype vaccines and beyond," Blood Reviews, vol. 23, no. 3, pp. 137 142, 2009.

[105] H. Wagner, "The immunogenicity of CpG-antigen conjugates," Advanced Drug Delivery Reviews, vol. 61, no. 3, pp. 243-247, 2009.

[106] J. M. Roda, R. Parihar, and W. E. Carson III, "CpGcontaining oligodeoxynucleotides act through TLR9 to enhance the NK cell cytokine response to antibody-coated tumor cells," Journal of Immunology, vol. 175, no. 3, pp. 16191627, 2005.

[107] M. J. Flaminio, A. S. Borges, D. V. Nydam, D. W. Horohov, R. Hecker, and M. B. Matychak, "The effect of CpG-ODN on antigen presenting cells of the foal," Journal of Immune Based Therapies and Vaccines, vol. 5, article 1, 2007.

[108] J. Vollmer and A. M. Krieg, "Immunotherapeutic applications of CpG oligodeoxynucleotide TLR9 agonists," Advanced Drug Delivery Reviews, vol. 61, no. 3, pp. 195-204, 2009.

[109] M. Ferrantini, I. Capone, and F. Belardelli, "Dendritic cells and cytokines in immune rejection of cancer," Cytokine and Growth Factor Reviews, vol. 19, no. 1, pp. 93-107, 2008.

[110] A. Perez-Garcia, S. Brunet, J. J. Berlanga, et al., "CTLA4 genotype and relapse incidence in patients with acute myeloid leukemia in first complete remission after induction chemotherapy," Leukemia, vol. 23, no. 3, pp. 486-491, 2009.

[111] A. Reichle and G. C. Hildebrandt, "Principles of modular tumor therapy," Cancer Microenvironment, vol. 2, supplement 1, pp. S227-S237, 2009.

[112] A. Dimberg, "Chemokines in angiogenesis," Current Topics in Microbiology and Immunology. In press.

[113] Y. Nakazaki, H. Hase, H. Inoue, et al., "Serial analysis of gene expression in progressing and regressing mouse tumors implicates the involvement of RANTES and TARC in antitumor immune responses," Molecular Therapy, vol. 14, no. 4, pp. 599-606, 2006.

[114] S. Song, C. Liu, J. Wang, et al., "Vaccination with combination of Fit3L and RANTES in a DNA prime-protein boost regimen elicits strong cell-mediated immunity and antitumor effect," Vaccine, vol. 27, no. 7, pp. 1111-1118, 2009.

[115] N. Lapteva, M. Aldrich, D. Weksberg, et al., "Targeting the intratumoral dendritic cells by the oncolytic adenoviral vaccine expressing RANTES elicits potent antitumor immunity," Journal of Immunotherapy, vol. 32, no. 2, pp. 145-156, 2009.

[116] E. M. Borroni, A. Mantovani, M. Locati, and R. Bonecchi, "Chemokine receptors intracellular trafficking," Pharmacology \& Therapeutics. In press.

[117] X. Zang and J. P. Allison, "The B7 family and cancer therapy: costimulation and coinhibition," Clinical Cancer Research, vol. 13, no. 18, pp. 5271-5279, 2007.

[118] J. Rosenblatt, Z. Wu, B. Vasir, et al., "Generation of tumorspecific $\mathrm{T}$ lymphocytes using dendritic cell/tumor fusions and anti-CD3/CD28," Journal of Immunotherapy, vol. 33, no. 2, pp. 155-166, 2010.
[119] R. Elgueta, M. J. Benson, V. C. de Vries, A. Wasiuk, Y. Guo, and R. J. Noelle, "Molecular mechanism and function of CD40/CD40L engagement in the immune system," Immunological Reviews, vol. 229, no. 1, pp. 152-172, 2009.

[120] H. J. Stauss, M. Cesco-Gaspere, S. Thomas, et al., "Monoclonal t-cell receptors: new reagents for cancer therapy," Molecular Therapy, vol. 15, no. 10, pp. 1744-1750, 2007.

[121] H. J. Stauss, S. Thomas, M. Cesco-Gaspere, et al., "WT1specific T cell receptor gene therapy: improving TCR function in transduced T cells," Blood Cells, Molecules, and Diseases, vol. 40, no. 1, pp. 113-116, 2008.

[122] C. T. Weaver, R. D. Hatton, P. R. Mangan, and L. E. Harrington, "IL-17 family cytokines and the expanding diversity of effector T cell lineages," Annual Review of Immunology, vol. 25, pp. 821-852, 2007.

[123] S. L. Gaffen, J. M. Kramer, J. J. Yu, and F. Shen, "The IL-17 cytokine family," Vitamins and Hormones, vol. 74, pp. 255282, 2006.

[124] Y. Bi, G. Liu, and R. Yang, "Th17 cell induction and immune regulatory effects," Journal of Cellular Physiology, vol. 211, no. 2, pp. 273-278, 2007.

[125] I. Kryczek, S. Wei, L. Zou, et al., "Cutting edge: Th17 and regulatory $\mathrm{T}$ cell dynamics and the regulation by IL-2 in the tumor microenvironment," Journal of Immunology, vol. 178, no. 11, pp. 6730-6733, 2007.

[126] N. Hirahara, Y. Nio, S. Sasaki, et al., "Inoculation of human interleukin-17 gene-transfected Meth-A fibrosarcoma cells induces T cell-dependent tumor-specific immunity in mice," Oncology, vol. 61, no. 1, pp. 79-89, 2001.

[127] M. C. Honorati, S. Neri, L. Cattini, and A. Facchini, "IL-17 enhances the susceptibility of U-2 OS osteosarcoma cells to NK cell lysis," Clinical and Experimental Immunology, vol. 133, no. 3, pp. 344-349, 2003.

[128] S. Sakaguchi, "Naturally arising foxp3-expressing $\mathrm{CD} 25^{+} \mathrm{CD} 4^{+}$regulatory $\mathrm{T}$ cells in immunological tolerance to self and non-self," Nature Immunology, vol. 6, no. 4, pp. 345-352, 2005.

[129] A. M. Gallegos and M. J. Bevan, "Central tolerance: good but imperfect,” Immunological Reviews, vol. 209, pp. 290-296, 2006.

[130] J. Shimizu, S. Yamazaki, and S. Sakaguchi, "Induction of tumor immunity by removing $\mathrm{CD} 25^{+} \mathrm{CD} 4^{+} \mathrm{T}$ cells: a common basis between tumor immunity and autoimmunity," Journal of Immunology, vol. 163, no. 10, pp. 5211-5218, 1999.

[131] M. Beyer, M. Kochanek, K. Darabi, et al., "Reduced frequencies and suppressive function of $\mathrm{CD} 4^{+} \mathrm{CD} 25^{h i}$ regulatory $\mathrm{T}$ cells in patients with chronic lymphocytic leukemia after therapy with fludarabine," Blood, vol. 106, no. 6, pp. 20182025, 2005.

[132] F. Ghiringhelli, N. Larmonier, E. Schmitt, et al., " $\mathrm{CD} 4{ }^{+} \mathrm{CD} 25^{+}$regulatory $\mathrm{T}$ cells suppress tumor immunity but are sensitive to cyclophosphamide which allows immunotherapy of established tumors to be curative," European Journal of Immunology, vol. 34, no. 2, pp. 336-344, 2004.

[133] S. Audia, A. Nicolas, D. Cathelin, et al., "Increase of $\mathrm{CD} 4{ }^{+} \mathrm{CD} 25^{+}$regulatory $\mathrm{T}$ cells in the peripheral blood of patients with metastatic carcinoma: a phase I clinical trial using cyclophosphamide and immunotherapy to eliminate $\mathrm{CD} 4{ }^{+} \mathrm{CD} 25^{+} \mathrm{T}$ lymphocytes," Clinical and Experimental Immunology, vol. 150, no. 3, pp. 523-530, 2007. 
[134] Y. Qu, B. Zhang, L. Zhao, et al., "The effect of immunosuppressive drug rapamycin on regulatory $\mathrm{CD} 4{ }^{+} \mathrm{CD} 25^{+}$foxp $3+\mathrm{T}$ cells in mice," Transplant Immunology, vol. 17, no. 3, pp. 153161, 2007.

[135] C. T. Garnett, J. Schlom, and J. W. Hodge, "Combination of docetaxel and recombinant vaccine enhances T-cell responses and antitumor activity: effects of docetaxel on immune enhancement," Clinical Cancer Research, vol. 14, no. 11, pp. 3536-3544, 2008.

[136] M. J. Szczepanski, M. Szajnik, M. Czystowska, et al., "Increased frequency and suppression by regulatory $\mathrm{T}$ cells in patients with acute myelogenous leukemia," Clinical Cancer Research, vol. 15, no. 10, pp. 3325-3332, 2009.

[137] E. M. Eisenstein and C. B. Williams, "The Treg/Th17 cell balance: a new paradigm for autoimmunity," Pediatric Research, vol. 65, pp. 26R-31R, 2009. 


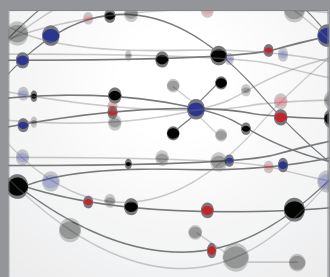

The Scientific World Journal
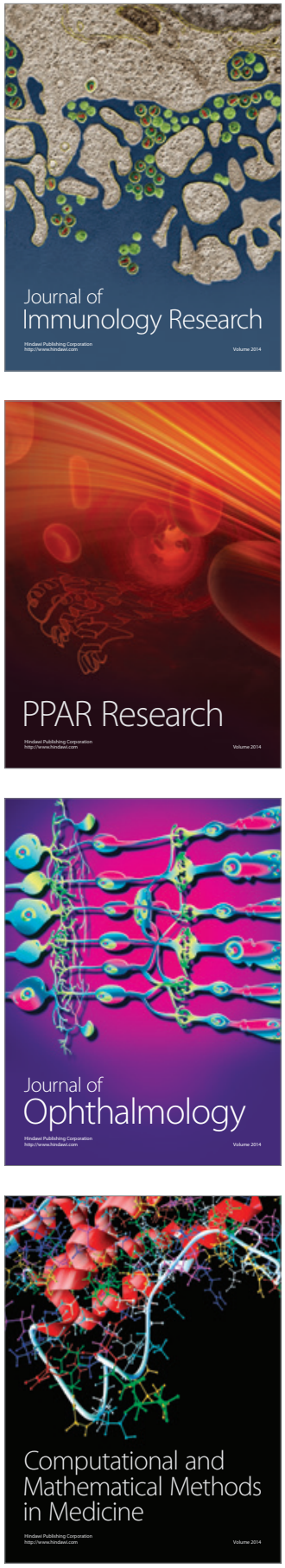

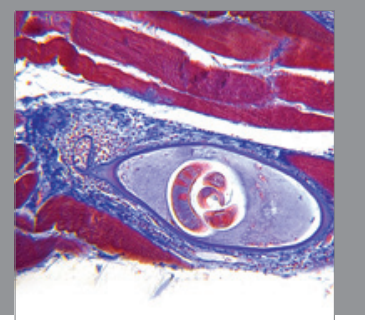

Gastroenterology

Research and Practice
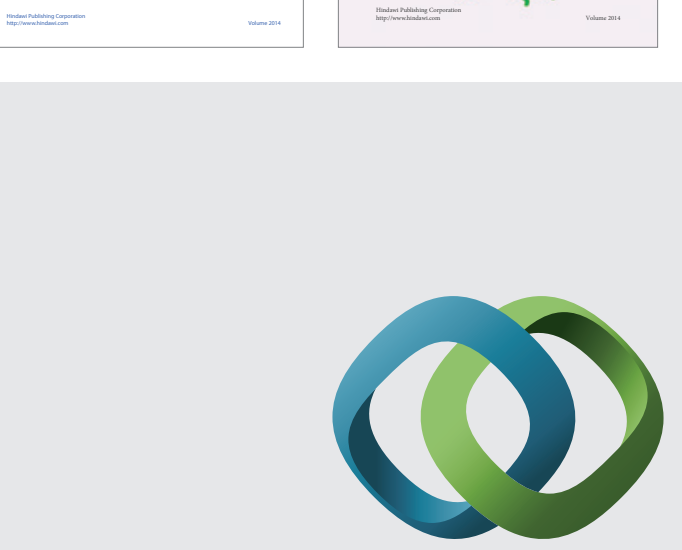

\section{Hindawi}

Submit your manuscripts at

http://www.hindawi.com
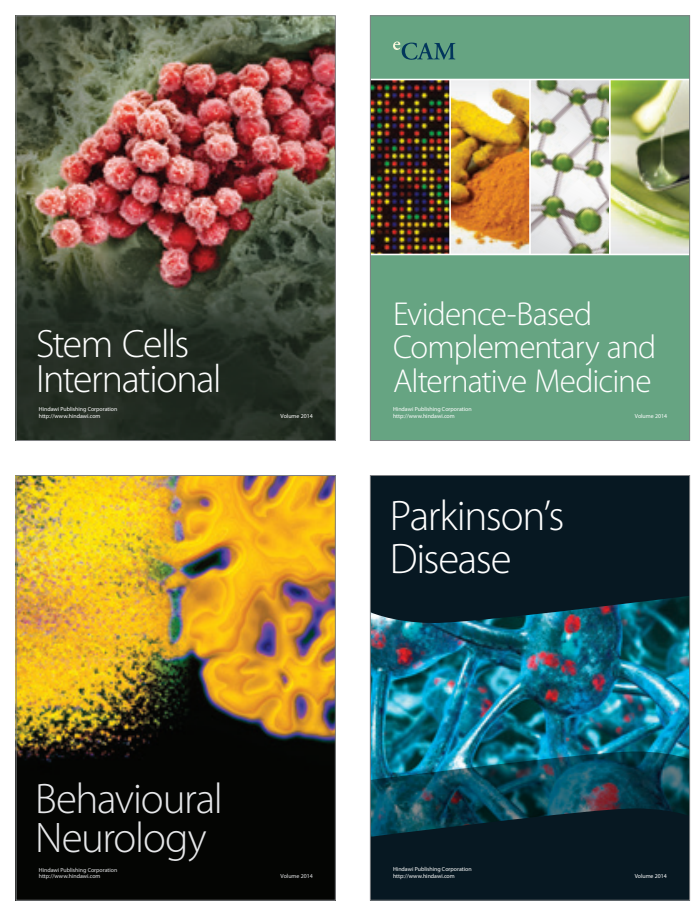

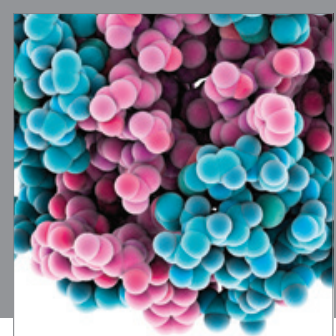

Journal of
Diabetes Research

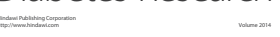

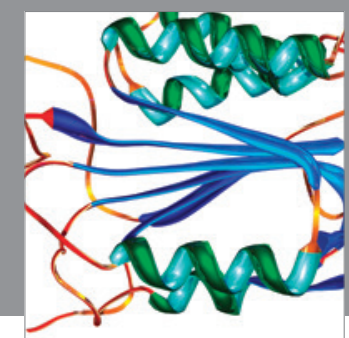

Disease Markers
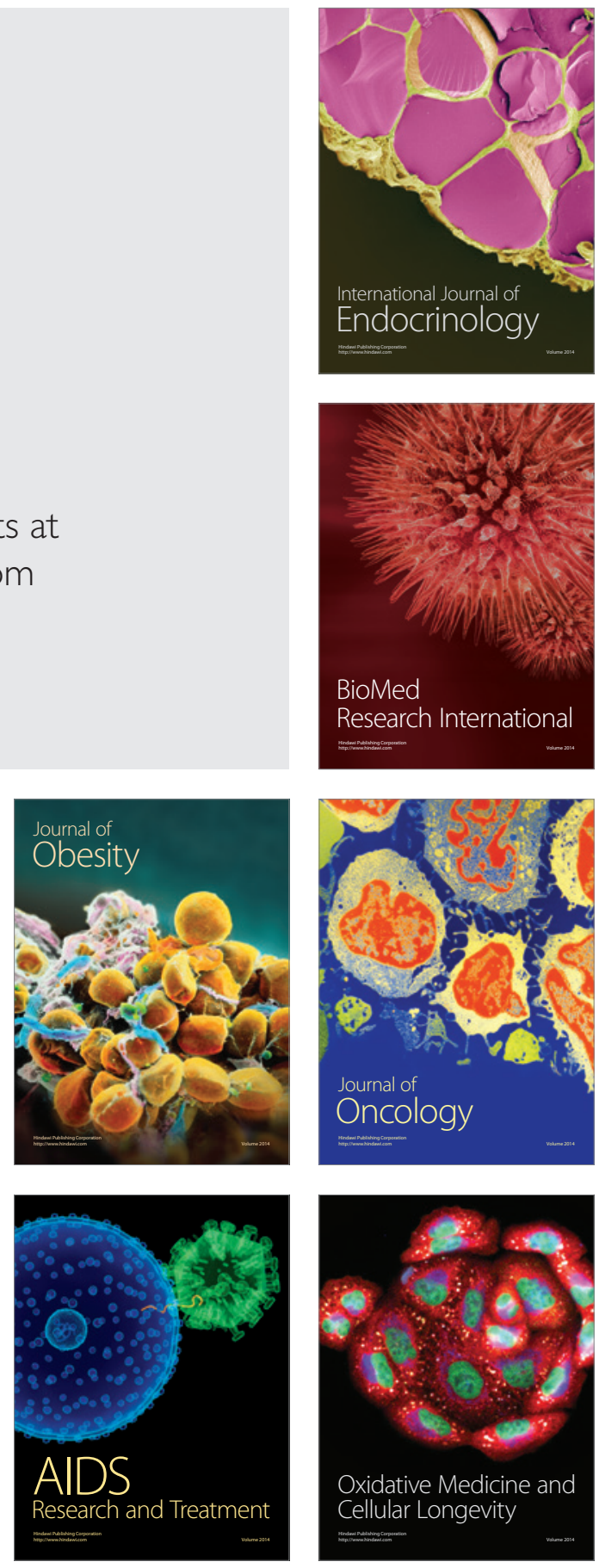